Nota de investigación

\title{
Tomato spotted wilt orthotospovirus (TSWV) no se trasmite por semilla de jitomate
}

Guadalupe Ríos Domínguez ${ }^{1}$

Martha Lidya Salgado Siclán ${ }^{2 \S}$

Carlos Aguilar Ortigoza ${ }^{3}$

Jesús Gaudencio Aquino Martínez ${ }^{4}$

José Francisco Ramírez Dávila²

${ }^{1}$ Ciencias Agropecuarias y Recursos Naturales-Facultad de Ciencias Agrícolas-Universidad Autónoma del Estado de México-Campus 'El Cerrillo', Toluca, México. CP. 50200. Tel. (722) 2965531. (casiopea42@hotmail.com). ${ }^{2}$ Facultad de Ciencias Agrícolas-Universidad Autónoma del Estado de México-Campus 'El Cerrillo', Toluca, México. CP. 50200. Tel. (722) 2965531 (jframirezd@uaemex.mx). ${ }^{3}$ Facultad de Ciencias-Universidad Autónoma del Estado de México-Campus 'El Cerrillo', Toluca, México. CP. 50200. Tel. (722) 2965554. (cjaguilaro@uaemex.mx; aguilarcj@yahoo.com.mx). ${ }^{4}$ Instituto de Investigación y Capacitación Agropecuaria, Acuícola y Forestal del Estado de México. Conjunto SEDAGRO s/n, Metepec, México. CP. 52140. Tel. (722) 2322922. (jg_aquino@ hotmail.com).

§Autora para correspondencia: mlsalgados@uaemex.mx.

\section{Resumen}

A la fecha, se reportan más de 231 virus capaces de ser transmitidos por semilla de manera externa o interna, esta transmisión constituye uno de los factores más importantes en el desarrollo epidemiológico de enfermedades de origen viral de precoz infección. El virus marchitez manchada del tomate tomato spot wilt orthotospovirus (TSWV), Orthotospoviridae) afecta a más de 900 familias de plantas incluyendo solanáceas, su principal transmisión es por insectos vectores como los trips, sin embargo, poco se conoce de su posible transmisión a través de semilla. El objetivo del presente trabajo fue determinar la posible trasmisión del TSWV por semilla de plantas de jitomate infectadas empleando técnicas serológicas y RT-PCR en su detección. Se colectaron frutos de jitomate provenientes de plantas infectadas de manera natural con TSWV previamente analizadas por Das-Elisa y positivas al virus de cuatro regiones del Estado de México. Posteriormente, se extrajeron las semillas de los frutos enfermos, a un grupo se les realizó la detección del virus por Das-Elisa en embrión y testa y el otro grupo de semillas se desarrollaron en cultivo in vitro por 15 días. Una vez obtenidas las plántulas, se llevó a cabo la extracción de ARN y la RT-PCR, usando los oligos específicos a la nucleocápside. Los análisis de embrión, semilla y plántulas in vitro con Das- Elisa y RT-PCR (respectivamente) resultaron ser negativos a TSWV en las muestras tratadas. Al parecer no existe infección por el virus en embrión, testa y plántulas in vitro de jitomate.

Palabras clave: Solanum lycopersicum L., in vitro, Das-Elisa, RT-PCR, semilla, TSWV.

Recibido: agosto de 2019

Aceptado: septiembre de 2019 
Los virus de plantas pueden ser diseminados por transmisión mecánica, propagación vegetativa, vectores, plantas parásitas, polen o semilla. Entre estas formas de transmisión, las ocurridas por semilla constituye uno de los factores más determinantes en el desarrollo epidemiológico de muchas enfermedades. La trasmisión de virus por semilla es de sumo interés debido a que causa: 1) reducción en la germinación; 2) amplia diseminación en el campo; y 3) fuente de inóculo primario en el desarrollo de enfermedades en diversos cultivos agrícolas (Sastry, 2013).

La trasmisión de virus por semilla en plantas y malezas ha sido estudiada desde los años 50', en ese espacio de tiempo se reportaron ocho especies de virus trasmitidos por semilla; a la fecha, se describen a más de 231 virus capaces de ser transmitidos a través de semilla de manera externa donde la partícula viral está presente en la cubierta de la semilla o interna cuando ésta se encuentra dentro de la semilla en el embrión o en el endospermo (Sastry, 2013), como se ha detectado utilizando técnicas con microscopio electrónico y serología con bean common mosaic virus (BCMV), pea seed-borne mosaic virus (PSbMV), tobacco ringspot virus (TRSV), lettucce mosaic virus) LMV, turnip yellow mosaic virus (TYMV) y cucumber mosaic virus (CMV) y con beet curly top virus (BCTV) y beet curly iran virus (BCTIV) en semillas de petunia, en estos la presencia del virus fue confirmada mediante PCR e IC-PCR respectivamente (Anabestani et al., 2017).

No obstante, de la presencia de algunos virus en semilla, su prevalencia decae conforme ésta madura, por efecto de la desecación que ocurre durante este proceso, como se demostró con rice yellow mottle virus (RYMV) en semilla de arroz. Similar no transmisión fue reportada en semilla de frijol infectada con Cowpea chlorotic mottle virus (CCMV) debido a la deshidratación de la semilla durante su desarrollo. Jain et al (2006), refieren que algunos virus transmitidos a través de semilla influyen en la interacción virus-hospedante que se trate, la raza del virus involucrada y condiciones del ambiente, como se observó en la transmisión de tomato streak virus (TSV); a través, de semilla de calabaza (Cucumis sativus).

Por otro lado, Prasada et al. (2009) no obtuvo el mismo resultado con este mismo virus en cacahuate y girasol. Referente a orthotospovirus, el tomato spotted wilt orthotospovirus (TSWV) no se transmitió en la testa de semillas maduras de cacahuate, pero si fue detectado en las recién cosechadas (Reddy et al., 1983). Así también, TSWV se reportó en semilla de Jacobaea maritima $($ senecio $=$ cineraria $)$; sin embargo, las pruebas serológicas no fueron del todo confiables debido a su baja prevalencia ( $1 \%$ de infección) y sobre todo a que el virus estuvo presente en la testa y no en el embrión (Zitter, 1991; Sastry, 2013).

Pappu et al. (1999) demostraron que TSWV fue localizado en vainas y testa de cacahuate a través de las técnicas ELISA y PCR en plantas sintomáticas a la infección del virus. Mediante PCR se detectó ocasionalmente a TSWV en los cotiledones mientras que, en plántulas obtenidas de semillas previamente evaluadas por Elisa, no se identificaron casos positivos, lo que sugiere que la acumulación de TSWV en cacahuate es localizado en la cascara y testa sin pasar a la progenie. Kritzman et al. (2007) reportaron que el iris yellow spot orthotospovirus (IYSV) no fue trasmitido a plántulas de cebolla (Allium cepa) de plantas madre infectadas.

Hajimorad et al. (2015) mencionan la ausencia de trasmisión del orthotospovirus Soybean vein necrosis virus (SVNV) en semilla de soya (Glycine max). Autores como Groves et al. (2016) reportaron por primera vez la trasmisión del orthotospovirus Soybean vein necrosis virus (SVNV) hasta 6\%; a través, del análisis de plántulas germinadas de semillas de soya (Glycine max) mediante 
PCR. Es bien sabido que la multiplicidad de factores afecta la transmisión de virus por semillas, por ejemplo: la cepa del virus, la especie huésped, el cultivar, el ambiente durante la producción de la semilla y el tiempo de inoculación de la planta.

Tales disimilitudes en la transmisión de virus hacen necesario confirmar su transmisión empleando técnicas moleculares que permitan esclarecer mejor este fenómeno. El objetivo del trabajo fue determinar la no trasmisión del TSWV en semilla de plantas de jitomate infectadas a través del uso de técnicas serológicas Das-Elisa y molecular RT-PCR.

Durante los meses de junio a septiembre de 2016 se realizaron muestreos dirigidos a plantas con síntomas característicos a TSWV como bronceado y pequeños anillos en las hojas y frutos en los municipios de Villa Guerrero, Villa Victoria, Chiltepec y Tlachaloya, Estado de México, en parcelas comerciales de jitomate cultivadas bajo invernadero. El método utilizado para la detección del virus TSWV en hojas de plantas con síntomas fue Das-Elisa siguiendo el protocolo establecido por la casa comercial Agdia ${ }^{\circledR}$. La lectura de absorbancia se llevó a cabo en un espectrofotómetro Thermo Scientific modelo Multiskan FC, a una longitud de onda de $405 \mathrm{~nm}$.

Las pruebas se realizaron por duplicado, se consideraron como positivos al virus aquellas lecturas cuya densidad óptica fue mayor o igual a tres veces la media del testigo negativo (Cruz y Frías, 1997). Posteriormente, se extrajo la semilla de los frutos de las plantas muestreadas con presencia del virus, separando el mesocarpio, lavadas con agua estéril y puestas sobre papel absorbente para ser almacenadas en bolsas de papel hasta su procesamiento en cultivo in vitro. Se conformaron seis tratamientos en base a su procedencia, incluyendo los testigos positivo y negativo.

Como primera intención de demostrar la detección del virus en la testa y embrión se realizó la técnica Das-Elisa. Se desinfestaron 12 semillas en un lavado con agua jabonosa por 3 min y un enjuague con agua destilada estéril, posteriormente la semilla se sumergió en una solución de hipoclorito de sodio $15 \%$ por unos segundos y nuevamente se enjuago con agua destilada estéril. Finalmente, la semilla se sumergió en etanol $75 \%$ durante $30 \mathrm{~s}$ con su posterior enjuague en agua. Seguido a la desinfestación, a través de un estereoscopio y dos agujas estériles se extrajo el embrión de la semilla, separando la testa para procesar por separado la detección del virus.

Por otro lado, la obtención de plántulas germinadas de semillas de los frutos de plantas infectadas se realizó con la técnica de cultivo in vitro de (Murashige and Skoog, 1962). Inicialmente las semillas se desinfestaron; a través, de un lavado en agua con detergente $(0.6 \mathrm{~g}$ de jabón en $100 \mathrm{~mL}$ de agua) durante 3 min más un enjuague con agua destilada, posteriormente se sumergieron en solución $15 \%$ de cloro comercial durante 5 min más un enjuague con agua destilada.

Por último, se hizo una inmersión de las semillas en alcohol-etanol $75 \%$ durante $30 \mathrm{~s}$ y se enjuagaron con agua destilada para realizar la siembra en el medio de cultivo. Se sembraron ocho semillas por frasco (con $25 \mathrm{~mL}$ de medio de cultivo MS, 1X libre de reguladores de crecimiento vegetal) que se incubaron en un cuarto de cultivo con ambiente controlado por 15 días (temperatura de $25{ }^{\circ} \mathrm{C}, 2000$ lux de intensidad y fotoperiodo de 16 h luz más 8 h oscuridad). La extracción de ARN de plántulas y callos provenientes de semillas de plantas infectadas con el virus se realizó con el reactivo Trizol, (Ambión $\left.{ }^{\circledR}\right)$. 
Una vez obtenido el ARN de cada tratamiento, se ejecutó la síntesis de cDNA mediante la reacción de transcripción reversa (RT) con $5 \mu \mathrm{L}$ de ARN total con el kit RevertAid First Strand cDNA Synthesis Kit ${ }^{\circledR}$ (Thermo Scientific) usando el cebador degenerado TOS-R15 (Uga y Tsuda, 2005). De manera siguiente se realizó una PCR punto final con el kit Kapa3G Plant PCR Kits ${ }^{\circledR}$ (Bio Systems) y $2 \mu \mathrm{L}$ de templado de cDNA con los iniciadores: TSWV-709 Forward: 5'-GTGTCATACTTCTTTGGGTC-3'; TOS-R15 Reverse: 5'GGGAGAGCAATYGWGKYR-3', que amplifican un fragmento de 709 pb de la región de la cápside del virus (Uga y Tsuda, 2005).

La amplificación se llevó acabo en un termociclador MJ Research Thermal ${ }^{\circledR}$ ) modelo PTC-100, con un programa que consistió en un paso inicial a $95{ }^{\circ} \mathrm{C}$ durante $2 \mathrm{~min}$, seguido de 35 ciclos con tres pasos: $95{ }^{\circ} \mathrm{C}$ por $20 \mathrm{~s}, 60{ }^{\circ} \mathrm{C}$ por $30 \mathrm{~s} \mathrm{y} 72{ }^{\circ} \mathrm{C}$ por 1 min, más una extensión final a $72{ }^{\circ} \mathrm{C}$ por 5 min y una conservación a $7{ }^{\circ} \mathrm{C}$ por $7 \mathrm{~min}$ (todas las pruebas se hicieron por triplicado). La visualización de los productos se llevó acabo por electroforesis en un gel de agarosa no desnaturalizante $1.5 \%$ con $1 \mu \mathrm{L}$ de bromuro de etidio, en un transiluminador Syngene ${ }^{\circledR}$, modelo GVM20.

Los resultados en todas las plantas de jitomate provenientes de campo de las diferentes regiones con síntomas a TSWV, mostraron ser positivas a la presencia del virus con la prueba Das-Elisa (Cuadro 1). En las plantas muestreadas prevaleció los síntomas de coloración bronceada, manchas café irregulares y algunos patrones de anillos sobre la epidermis, mientras que los frutos revelaron patrones de manchas irregulares de coloración café y aspecto resquebrajado sobre su superficie (Figura 1). Los síntomas causados por Orthotospovirus son muy variados, ya que depende de la edad de la planta, especie de virus y factores ambientales, muchas plantas responden a la infección viral con síntomas sistémicos (European Food Safety Authority, EFSA, 2012).

Cuadro 1. Resultados de la prueba Das-Elisa de hojas de plantas infectadas con TSWV, testa y embrión de semillas.

\begin{tabular}{|c|c|c|c|c|c|c|}
\hline Localidad & Muestra & Absorbancia & Resultado & Muestra & Absorbancia & Resultado \\
\hline \multirow[t]{2}{*}{ Villa Guerrero } & Hoja & 0.175 & Positivo & Testa & 0.014 & Negativo \\
\hline & & & & Embrión & 0.002 & Negativo \\
\hline \multirow[t]{2}{*}{ Villa Victoria } & Hoja & 0.189 & Positivo & Testa & 0.015 & Negativo \\
\hline & & & & Embrión & 0.003 & Negativo \\
\hline \multirow[t]{2}{*}{ Chiltepec } & Hoja & 0.214 & Positivo & Testa & 0.007 & Negativo \\
\hline & & & & Embrión & 0.003 & Negativo \\
\hline \multirow[t]{2}{*}{ Tlachaloya } & Hoja & 0.197 & Positivo & Testa & 0.004 & Negativo \\
\hline & & & & Embrión & 0.003 & Negativo \\
\hline \multirow[t]{2}{*}{ Control positivo* } & & 0.143 & & Testa & 0.11 & \\
\hline & & & & Embrión & 0.17 & \\
\hline \multirow[t]{2}{*}{ Control negativo* } & & 0.039 & & Testa & 0.02 & \\
\hline & & & & Embrión & 0.01 & \\
\hline
\end{tabular}



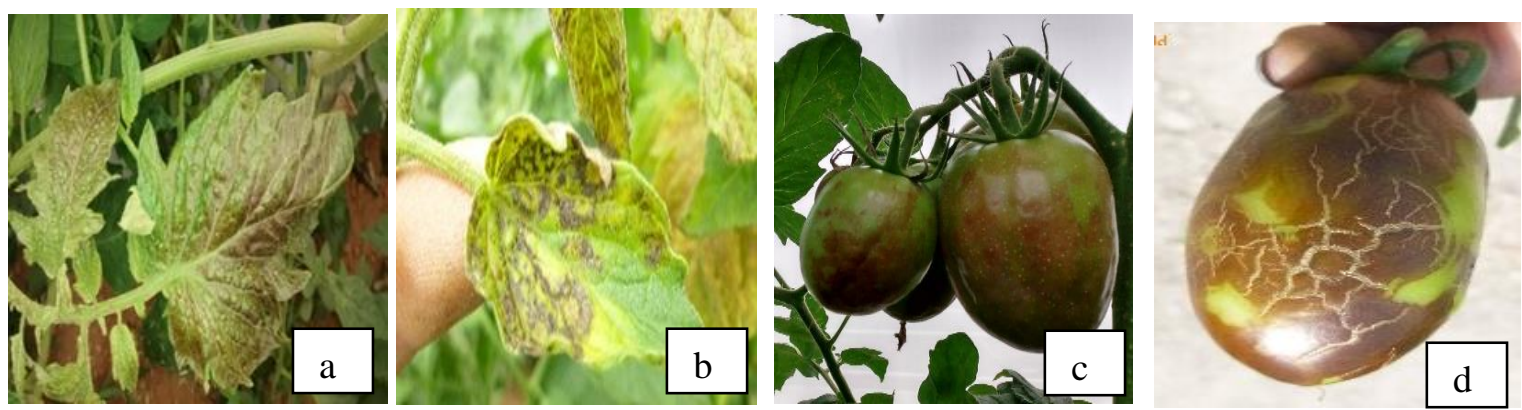

Figura 1. Síntomas de TSWV observados en follaje y frutos de plantas de jitomate: a) follaje con bronceado; b) manchas con anillos concéntricos en hoja; c) frutos con manchas café irregulares; y d) fruto con manchas oscuras y resquebrajadas.

El análisis por Das-Elisa en testa y embrión de semillas de las diferentes regiones fueron negativos (Cuadro 1), a pesar de que las plantas de donde fueron extraídas las semillas resultaron positivas en esta prueba.

Al respecto, Sastry (2013) señala que la mayoría de los virus son incapaces de infectar tanto células madre de plantas infectadas como embriones en desarrollo, debido a la falta de una conexión plasmodesmatal con el endospermo. Las leguminosas son la familia de plantas con mayor frecuencia de trasmisión de virus por semilla, debido que, en éstas las conexiones no se interrumpen durante el desarrollo de la semilla. Desde 1969, Bennet menciona que para que un virus pase de una generación a otra; a través, del embrión de la semilla, un factor muy determinante es la habilidad del virus para invadir el tejido meristemático e infectar gametofitos masculinos o femeninos en estados tempranos de desarrollo.

Además de la susceptibilidad gametofítica hacia la infección, lo que hasta la fecha ha sido difícil determinar. Whitfield y German (2005) indican que los Orthotospovirus son conocidos por su transmisión exclusiva de los trips.

Las plántulas crecidas in vitro mostraron una apariencia normal, sin alteración en su desarrollo, color y altura. Además, se observó desarrollo de callo solo en la localidad de Villa Victoria, México, (VVC). La extracción de ARN de estas plántulas mostró buena concentración, calidad y pureza. El ARN se visualizó en un gel de agarosa 1\% no desnaturalizante y buffer TAE. Con respecto a la RT-PCR de las muestras analizadas no se observó amplificación de banda del tamaño esperado al igual que el control negativo (plántula crecida in vitro proveniente de semilla comercial).

Contrariamente, el control positivo (follaje de planta infectada con TSWV), mostro la presencia de un amplicón de 709 pb. Los productos se observaron en un gel de agarosa 1.5\%. (Figura 2 B, C, D, E y F). La prueba serológica como Elisa es muy práctica y fiable, pero en la actualidad la alta sensibilidad y eficiencia de la reacción en cadena de la polimerasa (PCR) y sus variantes han mostrado ser las más eficientes y seguras para el análisis de virus (Eiras et al., 2001). 


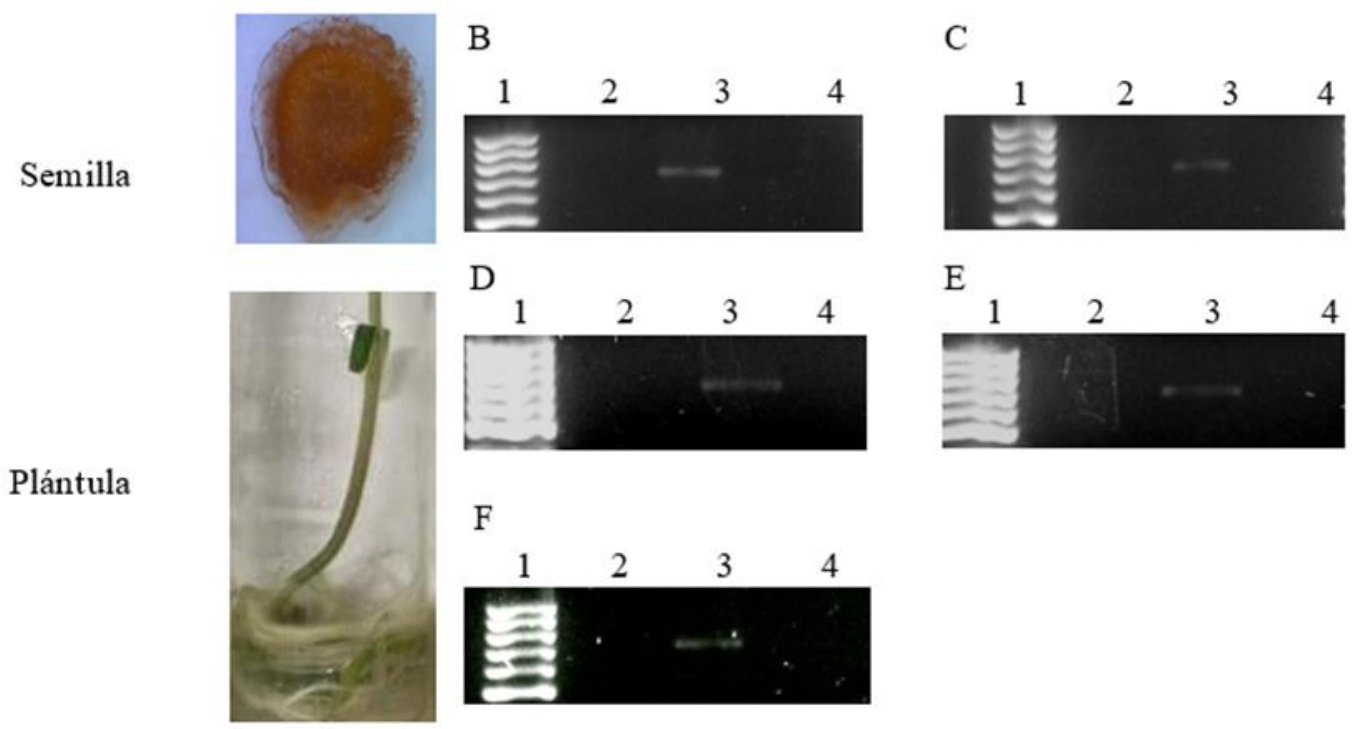

Figura 2. (A) Semilla y plántula germinada de jitomate in vitro; (B) producto de RT-PCR de TSWV de plántulas de Villa Guerrero (VG). Carril 1. Marcador molecular (Mm) Thermo Scientfic (100 pb), carril 2. Producto de PCR, carril 3. Control positivo, carril 4. Control negativo; (C) producto de RT-PCR de TSWV de plántulas de Villa Victoria; (D) producto de RTPCR de TSWV de callo de Villa Victoria; (E) producto de RT-PCR de TSWV de plántula de Chiltepec; y (F) producto de RT-PCR de TSWV de plántula de Tlachaloya. Gel de agarosa $1.5 \%, 65$ volts, 60 min.

\section{Conclusiones}

No existe trasmisión del virus TSWV en testa y en embrión de semilla provenientes de plantas infectadas de jitomate analizadas mediante la técnica Das-Elisa, de igual manera no se detectó la trasmisión del virus a plántulas provenientes de semilla de plantas infectadas analizadas por la técnica RT-PCR.

\section{Literatura citada}

Anabestani, A; Behjatnia, S. A. A; Izadpanah, K; Tabein, S. and Accotto, G. P. 2017. Seed transmission of beet curly top virus and beet curly top iran virus in local cultivar of petunia in Iran. Viruses. 9(10):299-311. doi: 10.3390/v9100299.

Bennet, C.W. 1969. Seed transmission of plant viruses. In: advances in virus research. Kennet M. Smith, Max A. Lauffer (Eds.). Academic Press. New York and London. 221-261 pp. doi: org/10.1016/S0065-3527(08)60561-8.

Cruz, M. y Frías, G. 1997. Guía Ilustrada de la prueba de inmunoadsorción con enzima ligada para la detección de fitopatógenos. Secretaría de Agricultura, Ganadería y Desarrollo Rural (SAGARPA). DF., México. 23 p.

Eiras, M; Resende, R. O.; e de Avila, A. C. 2001. Estratégia para a detecçāo de tospovírus. Arquivos do Instituto Biológico. Săo Paul 68(1):69-73. 
European Food Safety Authority (EFSA). 2012. Scientific opinion: scientific opinion of the pest categorisation of the tospovirus. Parma, Italy. EFSA Journal. 10(7):2772-2873. doi: 10.2903/j.efsa.2012.2772.

Groves, C; German, T; Dasgupta, R; Mueller, D. and Smith, L. 2016. Seed Transmission of Soybean vein necrosis virus: The First Tospovirus implicated in Seed Transmission. PLoS ONE. 11(1) e0147342. doi: 10. 1371/journal pone 0147342.

Hajimorad M. R; Halter M. C; Wang Y; Staton M. E. and Hershman D. E. 2015. Evaluation of seed transmissibility of Soybean Vein Necrosis-Associated Virus in two soybean cultivars grown under field conditions. Journal of Plant Pathology and Microbiology. 6:278-283. doi 10.4172/2157-7471.1000278.

Jain, R. K, Vemana K. and Bag, S. 2006. Tobacco streak virus an emerging virus in vegetables crops. In: Characterization, diagnosis and management of plant viruses. Rao, G. P; Kumar, P. L. and Holguin-Peña, R. J. (Eds). Vol. 3. Vegetable and pulse crops. Studium Press LLC. Houston, USA. 203-212 pp.

Kritzman A; Lampel M; Raccah B; and Gera A. 2007. Distribution and Transmission of Iris yellow spot virus. Plant Disease. 85(8):838-842.

Murashige, T. and Skoog, F. 1962. A revised medium for rapid growth and bioassays with tobacco tissue cultures. Physiol. Plant. 15(3):473-497.

Pappu, S. S; Pappu, H. R; Cullbreath, A. K. and Todd, J. W. 1999. Localization of tomato spotted wilt virus (genus Tospovirus, family Bunyaviridae) in peanut pods. Peanut Science. 26(2): 98-100.

Prasada Rao, R. D. V. J; Madhavi, K. J; Reddy, A. S; Varaprasad, K. S; Nigam, S. N; Sharma, K. K; Kumar, P. L. and Waliyar, F. 2009. Non-transmission of Tobacco streak virus isolated occurring in India through seed of some crop and weed hosts. Indian Journal Plant Protect. 3(1-2):92-96.

Reddy, D. V. R; Rajeshwari, R; Iizuka, N; Lesemann, D. E; Nolt, B. L. and Goto, T. 1983. The occurrence of Indian peanut clump, a soil-borne virus disease of groundnuts (Arachis hypogaea) in India. Annals of Applied Biology. 102(2):305-310.

Sastry, K. S. 2013. Seed-borne Plant Virus Diseases. Springer India. 327 p.

Uga, H. and Tsuda, S. 2005. A one reverse transcription-polymerase chain reaction system for the simultaneous detection and identification of multiple tospovirus infection. Phytopathology. doi: 10. 1094/PHYTO-95-0166.

Whitfield, A. E. and German, T. L. 2005. Tospovirus-thrips interactions. Annual Review Phytopathology. 43(1):459-489.

Zitter, T. A. 1991. Tomato Spotted wilt. In: compendium of tomato diseases. Jones, J. B; Jones, J. P; Stall, R. E. and Zitter, T. A. (Eds). APS PRESS. The American Phytopathological Society. MN. USA. 40 p. 